Org Lett. 2018 November 16; 20(22): 7293-7297. doi:10.1021/acs.orglett.8b03228.

\title{
Enantioselective Synthesis of a Cyclopropane Derivative of Spliceostatin A and Evaluation of Bioactivity
}

\author{
Arun K. Ghosh ${ }^{\star}, \dagger$, Guddeti Chandrashekar Reddy ${ }^{\dagger}$, Satish Kovela ${ }^{\dagger}$, Nicola Relitti ${ }^{\dagger}$, Veronica \\ K. Urabe ${ }^{\ddagger}$, Beth E. Prichard $\ddagger$, and Melissa S. Jurica ${ }^{\ddagger}$ \\ tDepartment of Chemistry and Department of Medicinal Chemistry, Purdue University, 560 Oval \\ Drive, West Lafayette, Indiana 47907 \\ ‡Department of Molecular Cell and Developmental Biology and Center for Molecular Biology of \\ RNA, University of California, Santa Cruz, California 95064
}

\begin{abstract}
Spliceostatin A is a potent inhibitor of spliceosomes and exhibits excellent anticancer activity against multiple human cancer cell lines. We describe here the design and synthesis of a stable cyclopropane derivative of spliceostatin A. The synthesis involved a cross-metathesis or a Suzuki cross-coupling reaction as the key step. The functionalized epoxy alcohol ring was constructed from commercially available optically active tri- $O$-acetyl-D-glucal. The biological properties of the cyclopropyl derivative revealed that it is active in human cells and inhibits splicing in vitro comparable to spliceostatin A.
\end{abstract}

\section{Graphical Abstract}<smiles>[CH]C1OC2C(OC3(C[C@H]4CO4)CC3)/C=C/C(C)=C/CC(C(C)CC1NC(=O)/C=C\C(C)OC(C)=O)[C@@H]2O</smiles>

cyclopropyl spliceostatin A

The majority of eukaryotic genes are expressed as precursor mRNAs (pre-mRNAs) which are then converted to mRNAs by splicing. ${ }^{1,2}$ This event is carried out by the multimegadalton ribonucleoprotein complex, spliceosome, which upon recognition of a splicing signal, catalyzes the removal of non-coding sequences (introns) and joins protein coding sequences (eons) to form messenger RNAs. ${ }^{3,4,5}$ These get exported to cytoplasm for translation into proteins. While these transcription and translation processes are complex,

\footnotetext{
*Corresponding Author akghosh@purdue.edu. ASSOCIATED CONTENT

Supporting Information

Experimental procedures in addition to ${ }^{1} \mathrm{H}$ - and ${ }^{13} \mathrm{C}$-NMR spectra are available for all new compounds. This material is available free of charge via the Internet at http://pubs.acs.org.

Supporting Information Available General experimental procedures, characterization data for all new products. This material is available free of charge via the Internet at http://pubs.acs.org.

The authors declare no competing financial interest.
} 
recent studies have demonstrated that splicing is pathologically altered to promote the initiation and maintenance of cancer. ${ }^{6,7}$ Splicing involves numerous protein-protein and protein-RNA interactions which offer opportunities to manipulate or inhibit the splicing cascade for therapeutic purposes, particularly in the area of anticancer drug development. ${ }^{8,9}$ Presently, a number of natural products and their derivatives are known to potently inhibit spliceosome function by binding to the SF3B subunit of U2 SnRNP. ${ }^{10,11,12}$ These include, FR901464 (1, Figure 1), spliceostatin A(2), pladienolide B (3), and a semisynthetic derivative E7O7, 4. $^{13,14,15}$ The precise molecular interactions of these molecules with SF3B are being investigated using cryo-electron microscopy. ${ }^{16,17,18}$ While these natural products display potent splicing activity their clinical use is limited due to chemical instability and inadequate physiochemical properties. To date, a semi synthetic derivative of pladienolide E7O7, (4), was developed with improved pharmacological properties for clinical development. ${ }^{19}$ A number of spliceostatin derivatives have seen specifically synthesized as payloads for antibody-drug conjugates. ${ }^{20,21}$ Both FR901464 (1) and spliceostatin A(2) show very potent antitumor properties. FR901464 displayed $\mathrm{IC}_{50}$ values ranging from 0.6 to 3.4 $\mathrm{nM}$ against multiple human cancer cell lines. It also showed effectiveness against solid tumors implanted in mice at a dose range of 0.05 to $1 \mathrm{mg} / \mathrm{kg} .{ }^{14,22}$ Spliceostatin A showed similar activity. As a result, these compounds attracted much attention for synthesis and medicinal chemistry development. We recently reported the synthesis and structure-activity studies of both these compounds. ${ }^{23,24}$ Nicolaou and co-workers also reported structural modifications of spliceostatin derivatives. ${ }^{25}$ In our continued interest in developing molecular probes for splicing studies, we devised cyclopropyl derivative of FR901464 and spliceostatin A, where a cyclopropane is incorporated at the anomeric site of FR901464 and spliceostatin A to improve stability and potency. We have devised an enantioselective synthesis of the epoxide subunit using readily available tri- $O$-acetyl-D-glucal as the key starting material and investigated coupling using cross-metathesis and Suzuki reactions. The synthesis will provide ready access to stable spliceostatin derivatives for biological studies.

Our synthetic strategy for the construction of the cyclopropyl derivative of spliceostatin A is shown in Scheme 1. We initially planned cross metathesis of diene $\mathbf{6}$ and epoxy olefin $\mathbf{8}$ using Grubbs' $2^{\text {nd }}$ generation catalyst. This cross metathesis reaction typically yields a mixture of olefin dimer, diene dimer, and the desired cross-coupling product. We also planned to investigate a Suzuki cross-coupling reaction between the known ${ }^{26,27}$ pinacol borononate $\mathbf{7}$ and vinyl iodide derivative $\mathbf{9}$ to provide the desired cross-coupling product 5 . The synthesis of pinacol boronate $\mathbf{7}$ would be achieved in optically active form using our recently reported procedure. ${ }^{27}$ The synthesis of cyclopropyl epoxide segment $\mathbf{8}$ or 9 would be carried out from alcohol 10 which would be derived from 4-methoxybenzylidene acetal 11 by reduction with Dibal-H. Acetal 11 can be synthesized from $\delta$-lactone 12 by synthetic manipulation from standard commercially available optically active tri- $O$-acetyl- $D$-glucal 13.

Enantioselective synthesis of 7-methylene-4-oxaspiro[2.5] octane derivative $\mathbf{1 0}$ is shown in Scheme 2. The preparation of benzylidene acetal 14 was carried out in multi-gram scale using commercially available tri- $O$-acetyl- $D$-glucal $\mathbf{1 3}$ with minor modifications. ${ }^{28}$ Treatment of 13 with $\mathrm{K}_{2} \mathrm{CO}_{3}$ in $\mathrm{MeOH}$ at $23{ }^{\circ} \mathrm{C}$ for $5 \mathrm{~h}$ provided the corresponding triol. 
Reaction of the resulting triol with 1-(dimethoxy)-4-methoxybenzene in the presence of a catalytic amount of PPTS at $23{ }^{\circ} \mathrm{C}$ for $2 \mathrm{~h}$ afforded benzylidene acetal 14. It was protected as the TBS-ether using TBSCl and imidazole in the presence of a catalytic amount of DMAP in DMF at $23{ }^{\circ} \mathrm{C}$ for $12 \mathrm{~h}$. The resulting TBS-ether was treated with NIS in a mixture (95:5) of $\mathrm{CH}_{3} \mathrm{CN}$ and water at $23{ }^{\circ} \mathrm{C}$ for $15 \mathrm{~min}$ and the mixture was concentrated. The residue was dissolved in DMF and saturated $\mathrm{NaHCO}_{3}$ and $\mathrm{Na}_{2} \mathrm{~S}_{2} \mathrm{O}_{4}$ were added and the mixture was stirred at $23{ }^{\circ} \mathrm{C}$ for $5 \mathrm{~h}$ to provide lactol $15 \mathrm{in} 81 \%$ yield over 2-steps. ${ }^{29,30}$ Oxidation of lactol 15 with Dess-Martin periodinane (DMP) in the presence of $\mathrm{NaHCO}_{3}$ in $\mathrm{CH}_{2} \mathrm{Cl}_{2}$ at $0{ }^{\circ} \mathrm{C}$ to $23{ }^{\circ} \mathrm{C}$ for $2 \mathrm{~h}$ furnished lactone derivative 16 in $81 \%$ yield. To install the cyclopropane ring, lactone 16 was treated with Petasis reagent ${ }^{31}$ in toluene at $23{ }^{\circ} \mathrm{C}$ and the resulting mixture was heated at $60{ }^{\circ} \mathrm{C}$ for $48 \mathrm{~h}$ to provide the corresponding enol-ether in $90 \%$ yield. Simmons-Smith cyclopropanation ${ }^{32}$ of the resulting enol ether with methylene diiodide and diethyl zinc in $\mathrm{CH}_{2} \mathrm{Cl}_{2}$ at $0{ }^{\circ} \mathrm{C}$ to $23{ }^{\circ} \mathrm{C}$ for $2 \mathrm{~h}$ afforded 4-oxaspiro[2,5]octane derivative $\mathbf{1 7}$ in $42 \%$ yield. Cyclopropane derivative $\mathbf{1 7}$ was converted to olefin $\mathbf{1 1}$ as follows. Treatment of TBS-ether $\mathbf{1 7}$ with TBAF in THF at $0{ }^{\circ} \mathrm{C}$ to $23{ }^{\circ} \mathrm{C}$ for $3 \mathrm{~h}$ provided the corresponding alcohol. Oxidation of the secondary alcohol to the corresponding ketone was achieved by treatment with DMP at $0{ }^{\circ} \mathrm{C}$ to $23^{\circ} \mathrm{C}$ for $2 \mathrm{~h}$. Wittig-olefination of the resulting ketone with methylenetriphenylphosphorane in THF at $0{ }^{\circ} \mathrm{C}$ to $23^{\circ} \mathrm{C}$ for $3 \mathrm{~h}$ provided $\mathbf{1 1}$ in $64 \%$ yield over 3 -steps. DIBAL-H reduction of benzylidene acetal 11 at $-78{ }^{\circ} \mathrm{C}$ to $0{ }^{\circ} \mathrm{C}$ for 4 $\mathrm{h}$ furnished alcohol 10 in $93 \%$ yield.

Conversion of alcohol 10 to epoxy alcohol derivatives $\mathbf{8}$ and $\mathbf{9}$ is shown in Scheme 3. Oxidation of alcohol 10 with DMP in the presence of $\mathrm{NaHCO}_{3}$ provided the corresponding aldehyde. Wittig-olefination of the resulting aldehyde with methylenetriphenylphosphorane in THF at $0{ }^{\circ} \mathrm{C}$ for $1 \mathrm{~h}$ afforded diene $\mathbf{1 8}$ in 53\% yield over 2-steps. Removal of the PMBgroup was carried out by exposure of $\mathbf{1 8}$ to DDQ in a mixture (10:1) of $\mathrm{CH}_{2} \mathrm{Cl}_{2}$ and phosphate buffer ( $\mathrm{pH} 7.2)$ at $0{ }^{\circ} \mathrm{C}$ for $2 \mathrm{~h}$ to furnish homoallylic alcohol 19. Selective epoxidation of 19 with a catalytic amount $(18 \mathrm{~mol} \%)$ of $\mathrm{VO}(\mathrm{acac})_{2}$ in the presence of $t$-butyl hydroperoxide in $\mathrm{CH}_{2} \mathrm{Cl}_{2}$ at $0{ }^{\circ} \mathrm{C}$ to $23{ }^{\circ} \mathrm{C}$ for $1.5 \mathrm{~h}$ provided epoxy alcohol derivative 8 as a single diastereomer (by ${ }^{1} \mathrm{H}-\mathrm{NMR}$ analysis) in $57 \%$ yield (73\% brsm). For the synthesis of vinyl iodide derivative $\mathbf{9}$, alcohol $\mathbf{1 0}$ was oxidized with $\mathrm{DMP}$ in the presence of $\mathrm{NaHCO}_{3}$ to provide the aldehyde in $48 \%$ yield. Takai olefination ${ }^{33}$ was carried out by reaction of the resulting aldehyde with a mixture of $\mathrm{CrCl}_{2}$ and $\mathrm{CHI}_{3}$ in THF at $23^{\circ} \mathrm{C}$ for $3 \mathrm{~h}$ to furnish vinyl iodide 20 in $85 \%$ yield. Exposure of PMB-derivative 20 to DDQ in a mixture of $\mathrm{CH}_{2} \mathrm{Cl}_{2}$ and phosphate buffer resulted in deprotection of the PMB-group. Directed epoxidation of the resulting allyic alcohol with $t$-butyl hydroperoxide in the presence of a catalytic amount (18 mol\%) of $\mathrm{VO}(\mathrm{acac})_{2}$ provided epoxy alcohol 9 in $64 \%$ yield over 2steps.

For the synthesis of the cyclopropyl derivative of spliceostatin A, we first carried out a cross metathesis ${ }^{34}$ reaction of diene $\mathbf{6}$ and epoxy olefin 8 as shown in Scheme 4. A mixture of epoxy olefin 8 and Grubbs' II catalyst (15 mol\%) in $\mathrm{CH}_{2} \mathrm{Cl}_{2}$ was prepared under argon atmostphere. To a stirred solution of diene $\mathbf{6}$ in $\mathrm{CH}_{2} \mathrm{Cl}_{2}$, a one-third portion of epoxy olefin 8 and Grubbs catalyst was added and the resulting mixture was heated at reflux for $1.5 \mathrm{~h}$. The other two portions of catalyst and olefin mixture were added successively in $1.5 \mathrm{~h}$ intervals.

Org Lett. Author manuscript; available in PMC 2019 November 16. 
The resulting mixture was stirred at reflux for an additional $1.5 \mathrm{~h}$ (total $8 \mathrm{~h}$ ). The reaction was cooled to $23{ }^{\circ} \mathrm{C}$ and the mixture was concentrated. The residue was purified by silica gel chromatography to furnish cyclopropane derivative $\mathbf{5}$ in $27 \%$ yield. The cross metathesis reaction also provided an inseparable mixture of epoxide dimer and diene dimer as the byproducts (21 and 22, about 25-30\%). We then investigated a Suzuki coupling ${ }^{35}$ of known boronate 7 and vinyl iodide derivative 9 using $\mathrm{Pd}(\mathrm{dppf})_{2} \mathrm{Cl}_{2} \cdot \mathrm{DCM}(10 \mathrm{~mol} \%)$ catalyst in the presence of aqueous $\mathrm{Cs}_{2} \mathrm{CO}_{3}$ in THF at $23{ }^{\circ} \mathrm{C}$ for $30 \mathrm{~min}$ to provide the coupling product 5 in $29 \%$ yield. The yield for coupling product 5 via cross-metathesis or Suzuki coupling was comparable.

We evaluated the biological activity of this cyclopropane spliceostatin A (5) in an in vitro splicing system as previously described. ${ }^{36}$ The compound inhibits splicing, but at a slightly reduced ( 2-fold lower) potency relative to spliceostatin A (Figure 2 ). The compound is also active in HeLa cells. It induces the coalescence of nuclear speckles as observed by immunostaining of the splicing factor SFRS2 at similar levels as spliceostatin A (Figure 3).

In summary, we reported the design, synthesis, and biological evaluation of a cyclopropane derivative of spliceostatin A and FR901464. The synthesis of the cyclopropane derivatives 8 and $\mathbf{9}$ for coupling reactions was carried out enantioselectively from commercially available, optically active tri- $O$-acetyl- $D$-glucal. We have investigated both a cross-metathesis route as well as a Suzuki coupling and both coupling reactions provided the final derivative in comparable yield.

Our design of cyclopropane ring conceivably removed one chiral center and also improved chemical stability of the resulting cyclopropane derivative. We have evaluated spliceosome inhibitory activity of the cyclopropane derivative $\mathbf{5}$ and compared its activity with spliceostatin A. The compound is very active in HeLa cells. Also, compound $\mathbf{5}$ induces the coalescence of nuclear speckles at a similar level to spliceostatin A. As it turns out, the cyclopropane derivative exhibited comparable potency to spliceostatin A. Further design and synthesis of structural variants of spliceostatins are underway.

\section{Supplementary Material}

Refer to Web version on PubMed Central for supplementary material.

\section{ACKNOWLEDGMENT}

Financial support of this work was provided by the National Institutes of Health (GM122279) and Purdue University. The authors thank Ms. Hannah Simpson and Mr. Josh Born (both, Purdue University) for valuable discussions

\section{REFERENCES}

1. Roybal GA; Jurica MS Nucleic Acids Res 2010, 38, 6664-6672. [PubMed: 20529876]

2. Wahl MC; Will CL; Lührmann R Cell 2009, 136, 701-718. [PubMed: 19239890]

3. Shi Y Nat. Rev. Mol. Cell. Biol 2017, 18, 655-670. [PubMed: 28951565]

4. Will CL; Luhrmann R Cold Spring Harb. Perspect Biol 2011, 3.

5. Raymond B Nat. Chem. Biol 2007, 3, 533-535. [PubMed: 17710096]

Org Lett. Author manuscript; available in PMC 2019 November 16. 
6. Van Alphen RJ; Wiemer EA; Burger H; Eskens FA Br. J. Cancer 2009, 100, 228-232. [PubMed: 19034274]

7. Cooper TA; Wan L; Dreyfuss G Cell 2009, 136, 777-793. [PubMed: 19239895]

8. Lee SC-W; Abdel-Wahab O Nat. Med 2016, 22, 976-986. [PubMed: 27603132]

9. Pal S; Gupta R; Kim H; Wickramasinghe P; Baubet V; Showe LC; Dahmane N; Davuluri RV Genome Res 2011, 21, 1260-1272. [PubMed: 21712398]

10. Van Alphen RJ; Wiemer EAC; Burger H; Eskens FALM Brit. J. Cancer 2009, 100, 228-232. [PubMed: 19034274]

11. Hsu TY-T; Simon LM; Neill NJ; Marcotte R; Sayad A; Bland CS; Echeverria GV; Sun T; Kurley SJ; Tyagi S; Karlin KL; Dominguez-Vidaña R; Hartman JD; Renwick A; Scorsone K; Bernardi RJ; Skinner SO; Jain A; Orellana M; Lagisetti C; Golding I; Jung SY; Neilson JR; Zhang XH-F; Cooper TA; Webb TR; Neel BG; Shaw CA; Westbrook TF Nature, 2015, 525, 384-388. [PubMed: 26331541]

12. Sidarovich A; Will CL; Anokhina MM; Ceballos J; Sievers S; Agafonov DE; Samatov T; Bao P; Kastner B; Urlaub H; Waldmann H; Lührmann R eLife, 2017, 6, e23533. [PubMed: 28300534]

13. Sakai T; Sameshima T; Matsufuji M; Kawamura N; Dobashi K; Mizui Y J. Antibiot 2004, 57, 173-179. [PubMed: 15152802]

14. Sakai T; Asai N; Okuda A; Kawamura N; Mizui Y .J. Antibiot 2004, 57, 180-187. [PubMed: 15152803]

15. Sato M; Muguruma N; Nakagawa T; Okamoto K; Kimura T; Kitamura S; Yano H; Sannomiya K; Goji T; Miyamoto H; Okahisa T; Mikasa H; Wada S; Iwata M; Takayama T Cancer Sci 2014, 105, 110-116. [PubMed: 24635824]

16. Kotake Y; Sagane K; Owa T; Mimori-Kiyosue Y; Shimizu H; Uesugi M; Ishihama Y; Iwata M; Mizui Y Nat. Chem. Biol 2007, 3, 570-575. [PubMed: 17643112]

17. Yokoi A; Kotake Y; Takahashi K; Kadowaki T; Matsumoto Y; Minoshima Y; Sugi NH; Sagane K; Hamaguchi M; Iwata M; Mizui Y FEBS J 2011, 278, 4870-4880. [PubMed: 21981285]

18. Galej WP; Wilkinson ME; Fica SM; Oubridge C; Newman AJ; Nagai K Nature 2016, 537, $197-$ 201. [PubMed: 27459055]

19. Bonnal S; Vigevani L; Valcárcel Nat. Rev. Drug Discov 2012, 11, 847-859. [PubMed: 23123942]

20. Beck A; Goetsch L; Dumontet C; Corvaïa N Nat. Rev. Drug Discov 2017, 16, 315-337. [PubMed: 28303026]

21. Bessire AJ; Ballard TE; Charati M; Cohen J; Green M; Lam M-H; Loganzo F; Nolting B; Pierce B; Puthenveetil S; Roberts L; Schildknegt K; Subramanyam C Bioconjugate Chem 2016, 27 , 1645-1654.

22. Mizui Y; Sakai T; Iwata M; Uenaka T; Okamoto K; Shimizu H; Yamori T; Yoshimatsu K; Asada M J. Antibiot 2004, 57, 188-196. [PubMed: 15152804]

23. Ghosh AK; Chen Z-H Org. Lett 2013, 15, 5088-5091. [PubMed: 24050251]

24. Ghosh AK; Chen Z-H; Effenberger KA; Jurica MS J. Org. Chem 2014, 79, 5697-5709. [PubMed: 24873648]

25. Nicolaou KC; Rhoades D; Kumar SM J. Am. Chem. Soc 2018, 140, 8303-8320. [PubMed: 29943984]

26. Nicolaou KC; Rhoades D; Lamani M; Pattanayak MR; Kumar SM J. Am. Chem. Soc 2016, 138, 7532-7535. [PubMed: 27266914]

27. Ghosh AK; Reddy GC;MacRae AJ; Jurica MS J. Org. Chem 2018, 26, 96-99.

28. Bartolozzi A; Pacciani S; Benvenuti C; Cacciarini M; Liguori F; Menichetti S; Nativi C J. Org. Chem 2003, 68, 8529-8533. [PubMed: 14575481]

29. Koviach JL; Chappell MD; Halcomb RL J. Org. Chem 2001, 66, 2318-2326. [PubMed: 11281772]

30. Bolitt V; Mioskowski C; Lee SG; Falck JR J. Org. Chem 1990, 55, 5812-5813.

31. Petasis NA; Bzowej EI J. Am. Chem. Soc 1990, 112, 6392-6394.

32. Lebel H; Marcoux J-F; Molinaro C; Charette AB Chem. Rev 2003, 103, 977-1050. [PubMed: 12683775]

33. Takai K; Nitta K; Utimoto K J. Am. Chem. Soc 1986, 108, 7408-7410.

Org Lett. Author manuscript; available in PMC 2019 November 16. 
34. Chatterjee AK; Choi T-L; Sanders DP; Grubbs RH J. Am. Chem. Soc 2003, 125, 11360-11370. [PubMed: 16220959]

35. Suzuki A J. Organomet. Chem 1999, 576, 147-168.

36. Effenberger KA; Anderson DD; Bray WM; Prichard BE; Ma N; Adams MS; Ghosh AK; Jurica MS J. Biol. Chem 2014, 289, 1938-1947. [PubMed: 24302718] 


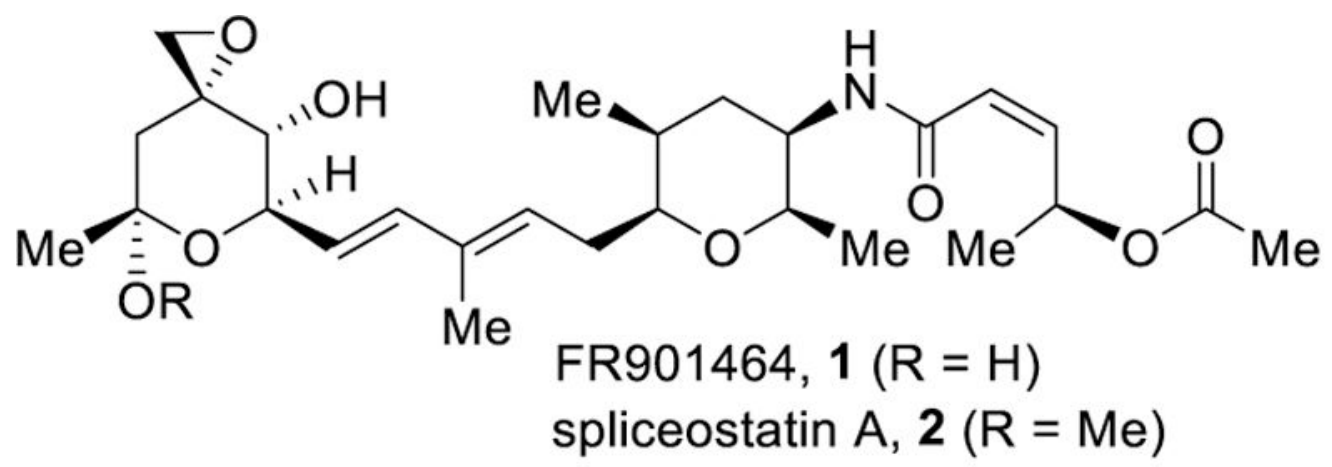

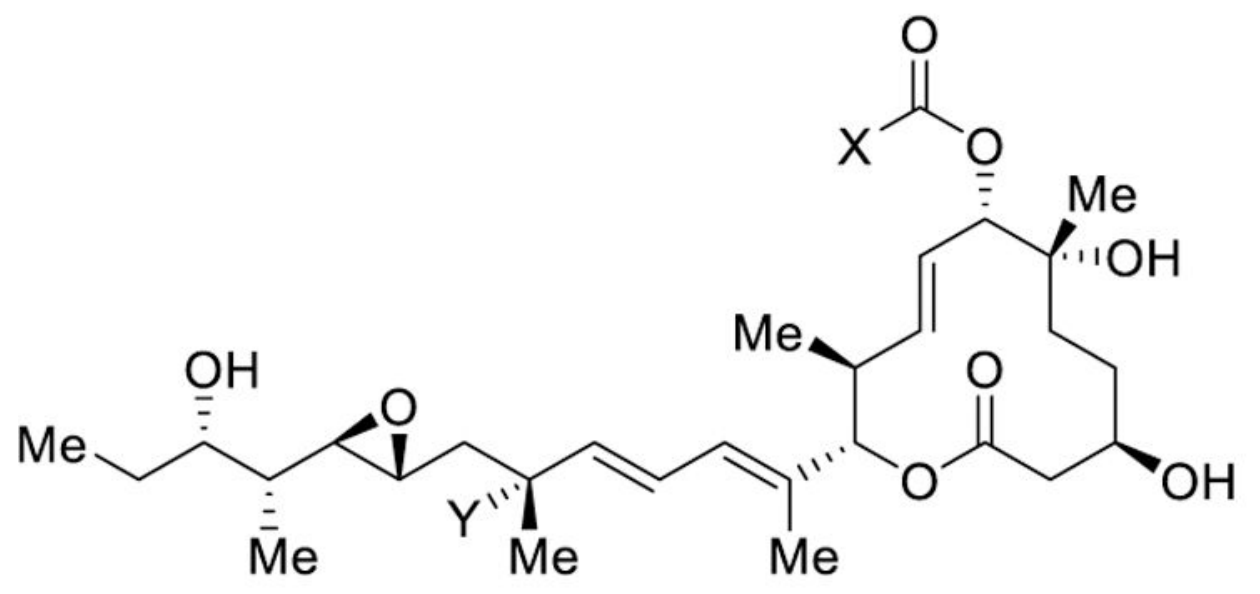

pladienolide $B, 3(X=M e, Y=H)$

E7O7, 4 ( $X=4$-cycloheptylpiperazin-1-yl; $Y=O H$ )

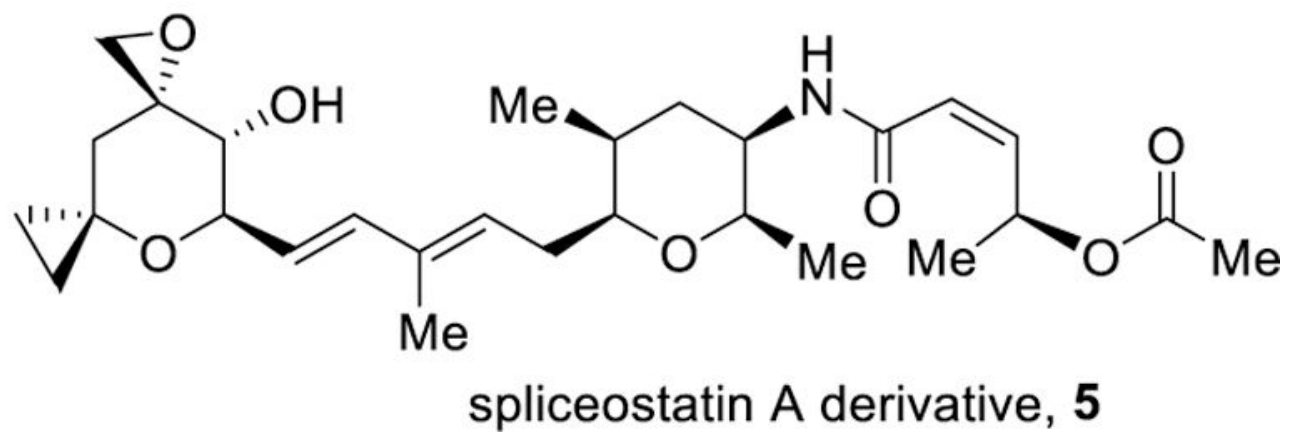

Figure 1.

Structures of spliceosome inhibitors 1-5 


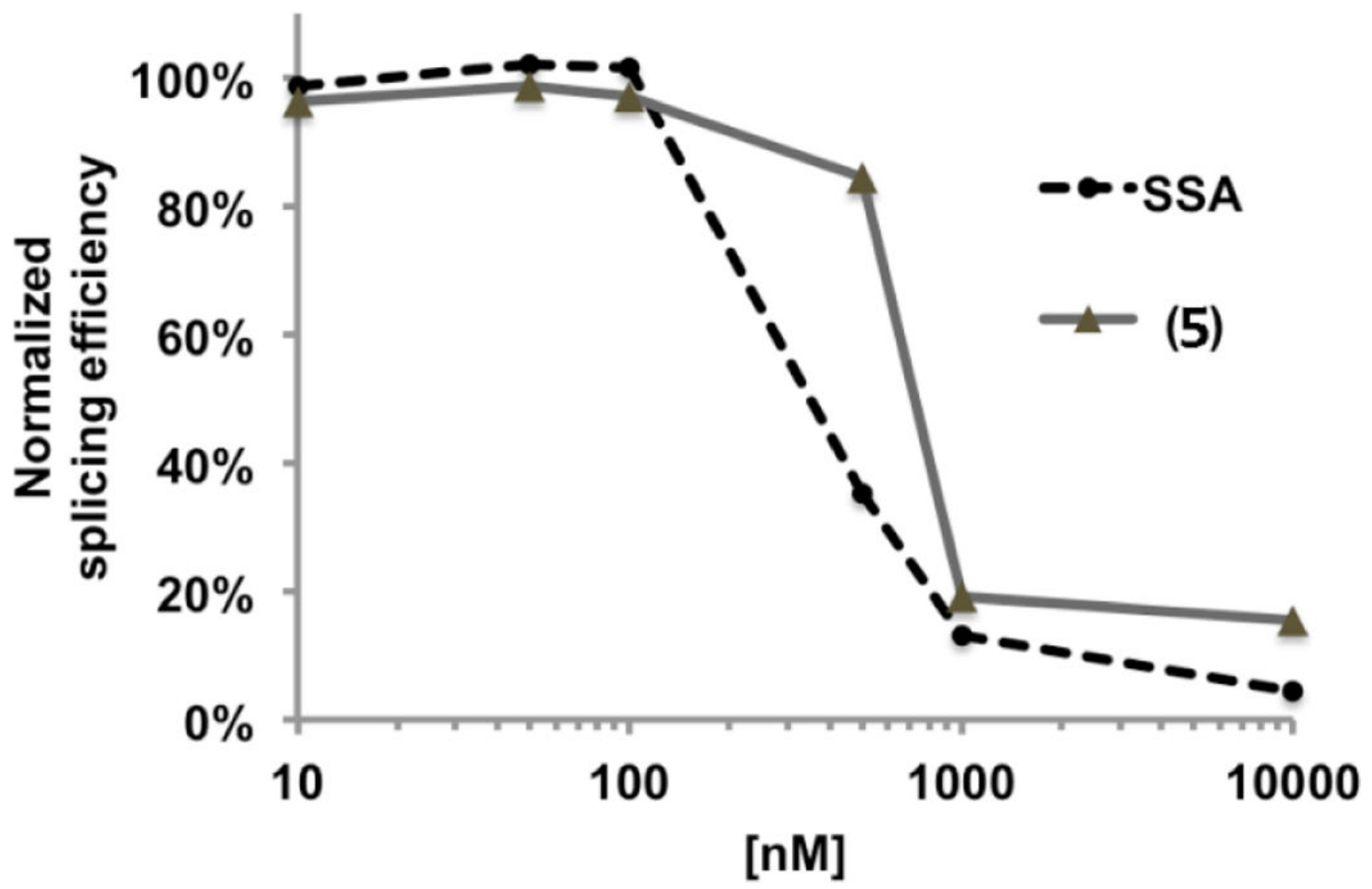

Figure 2.

Impact of compound 5 on in vitro splicing. Average splicing efficiency relative to inhibitor concentration normalized to no-drug control. Compound 5; SSA, spliceostatin A. 


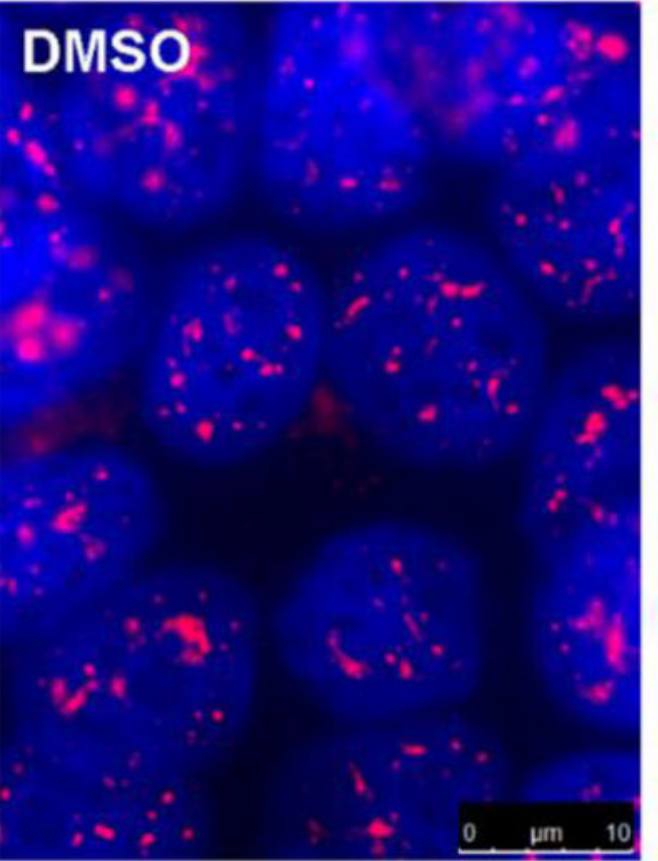

\section{$0.1 \mu \mathrm{M}(5)$}

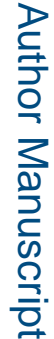

$1 \mu \mathrm{M}$ SSA (4)

\section{$1 \mu \mathrm{M}(5)$}
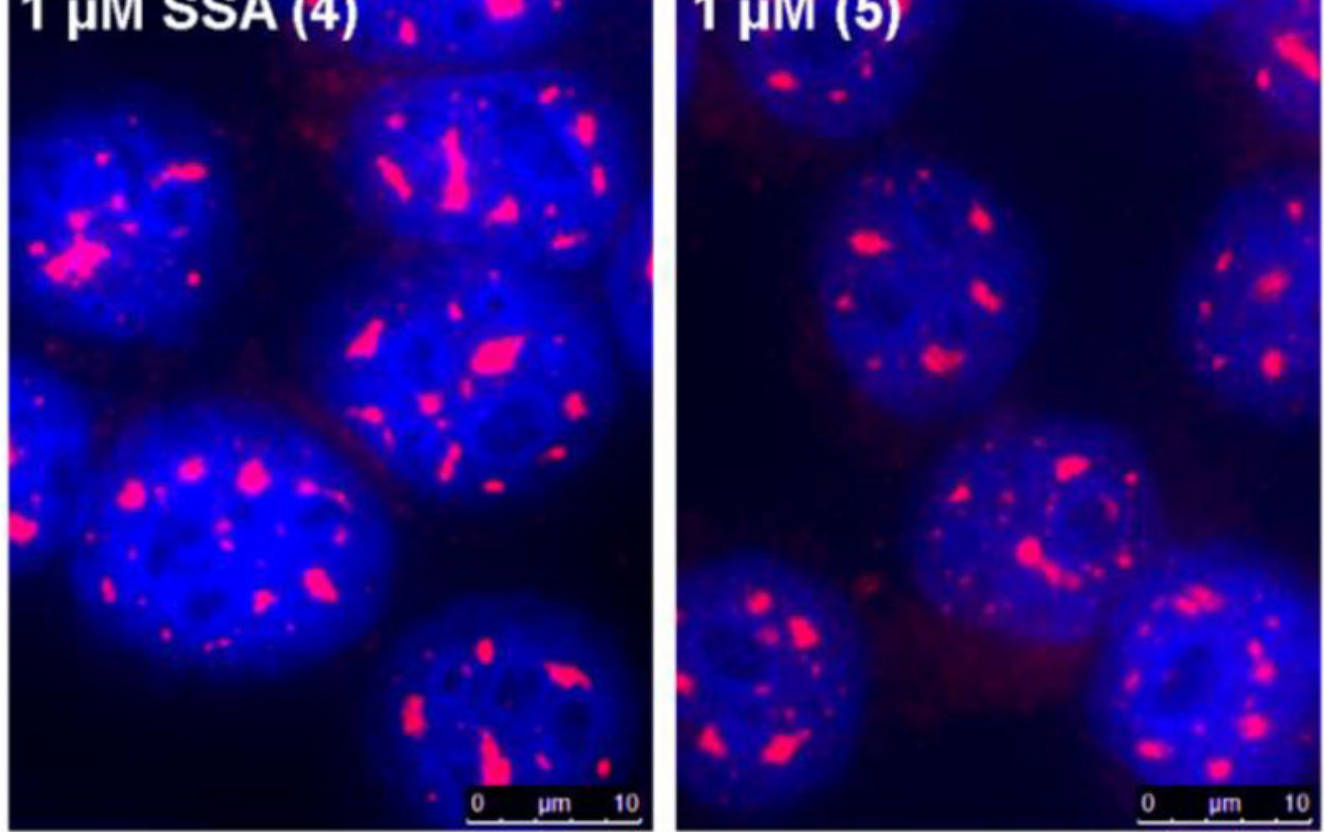

Figure 3.

Changes in nuclear speckle morphology. Fluorescent images of in HeLa cells nuclei incubated four hours with the indicated compound, then fixed and stained with DAPI (blue) and anti-SRSF2 antibody (magenta). 


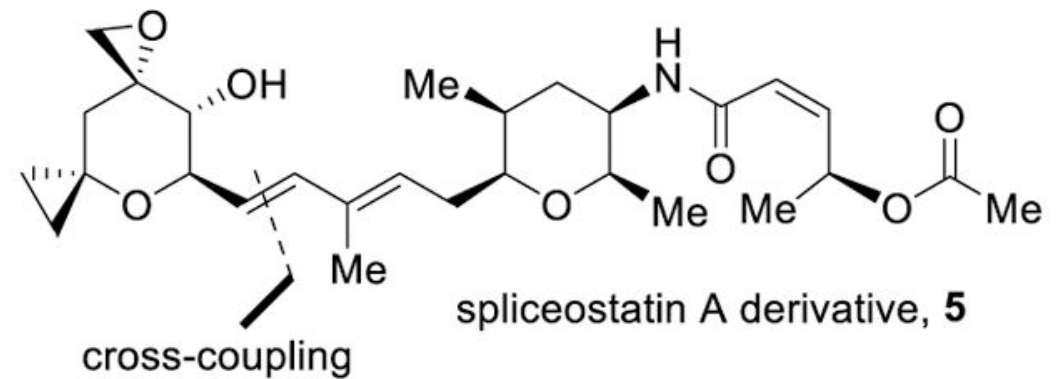<smiles>C=CC</smiles><smiles></smiles><smiles>CCCCC</smiles><smiles>C=C1CC2(CC2)O[C@H](CO)[C@@H]1OCc1ccc(OC)cc1</smiles>

10<smiles>CC(=O)OC[C@H]1OC=C[C@H](OC(C)=O)[C@@H]1OC(C)=O</smiles>

13<smiles>C=C1CC2(CC2)O[C@@H]2COC(c3ccc(OC)cc3)O[C@H]12</smiles>

11<smiles>COc1ccc(C2OC[C@H]3OC(=O)C[C@@H](OP)[C@H]3O2)cc1</smiles>

12

Scheme 1.

Retrosynthesis of spliceostatin derivative 
<smiles>CC(=O)OC[C@H]1OC=C[C@H](OC(C)=O)[C@@H]1OC(C)=O</smiles>

13
1. $\mathrm{K}_{2} \mathrm{CO}_{3}(2 \mathrm{~mol} \%)$, $\mathrm{MeOH}, 23^{\circ} \mathrm{C}, 5 \mathrm{~h}$

2. 4- $\mathrm{MeO}\left(\mathrm{C}_{6} \mathrm{H}_{4}\right)-$ $\mathrm{CH}(\mathrm{OMe})_{2}$ (1.4 equiv) PPTS ( 0.2 equiv), THF 2 -steps $23^{\circ} \mathrm{C}, 2 \mathrm{~h}$

1. $\mathrm{TBSCl}$ (1.2 equiv) imidazole (2.4 equiv) DMAP (0.1 equiv) DMF, $23^{\circ} \mathrm{C}, 12 \mathrm{~h}$

$81 \%$

2. NIS (1.1 equiv) $\mathrm{CH}_{3} \mathrm{CN}: \mathrm{H}_{2} \mathrm{O}$ then, sat. $\mathrm{NaHCO}_{3}$ $\mathrm{Na}_{2} \mathrm{~S}_{2} \mathrm{O}_{4}$ (4 equiv)<smiles>COc1ccc(C2OC[C@H]3OC=C[C@H](O)[C@H]3O2)cc1</smiles>
DMF, $23^{\circ} \mathrm{C}, 5 \mathrm{~h}$<smiles>COc1ccc(C2OC[C@H]3O[C@H](O)C[C@H](O[Sb])[C@H]3O2)cc1</smiles>

15 1. $\mathrm{Cp}_{2} \mathrm{Ti}\left(\mathrm{CH}_{3}\right)_{2}$ (2 equiv) PhMe, $60^{\circ} \mathrm{C}, 48 \mathrm{~h}$ darkness

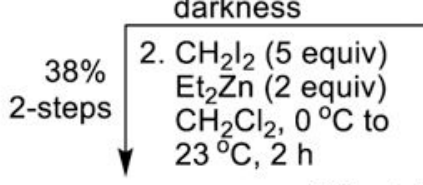<smiles>COc1ccc(C2OC[C@H]3OC(=O)C[C@@H](O)[C@H]3O2)cc1</smiles><smiles>C=C1CC2(CC2)O[C@@H](CO)[C@@H]1OCc1ccc(OC)cc1</smiles>

Scheme 2.

Synthesis of dihydropyranone $\mathbf{1 8}$ 


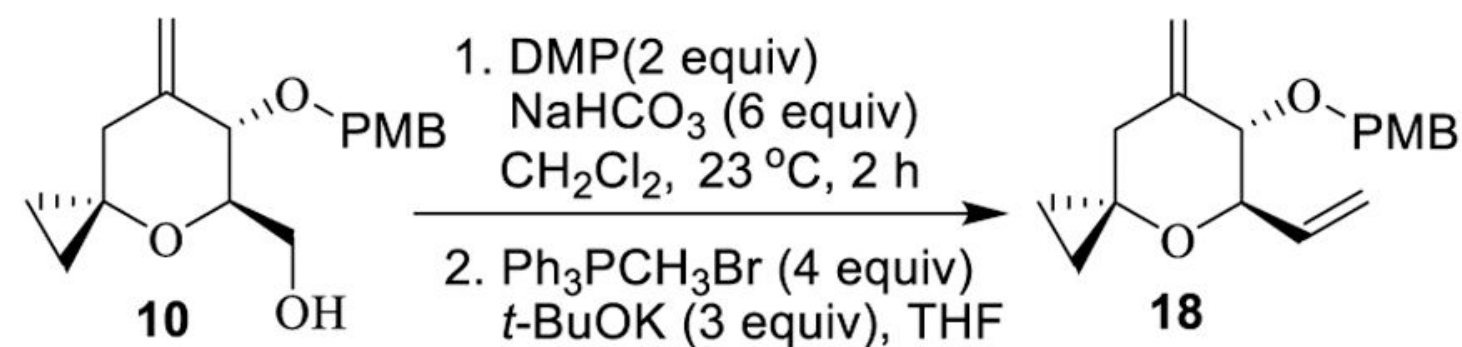
$0{ }^{\circ} \mathrm{C}, 1 \mathrm{~h}$

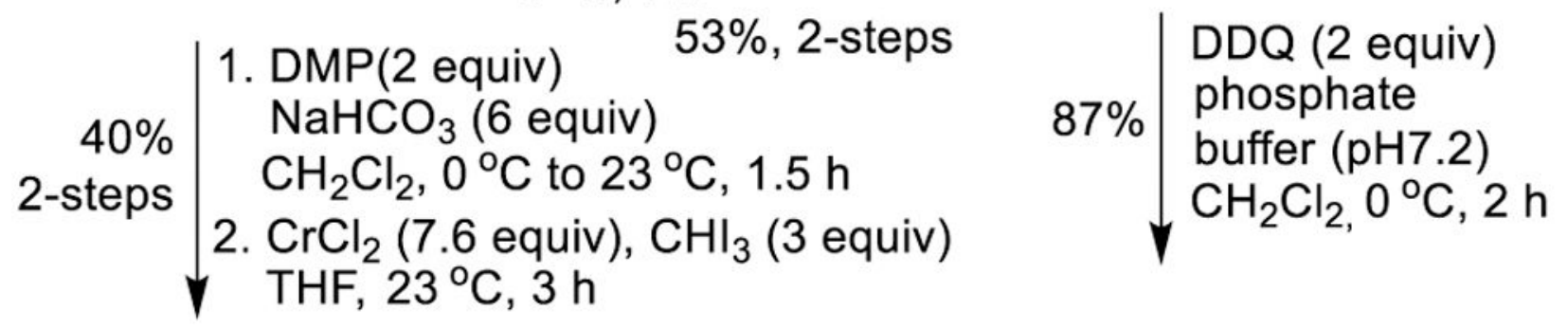<smiles>[R16]O[C@H]1C(=C)CC2(CC2)O[C@@H]1/C=C/I</smiles>

20

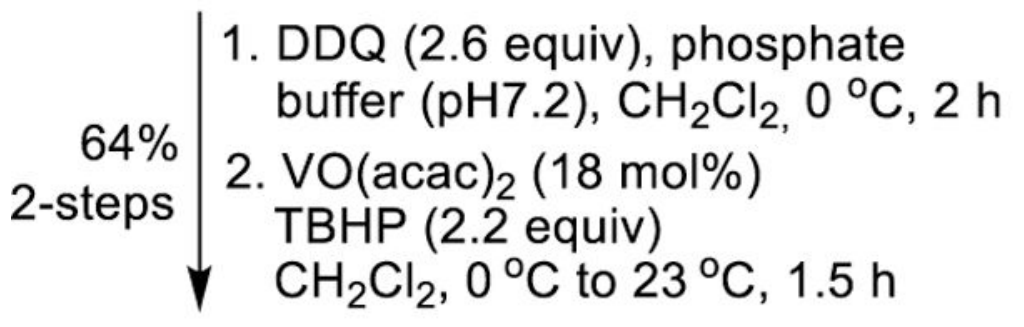<smiles>O[C@H]1[C@H](/C=C/I)OC2(CC2)C[C@@]12CO2</smiles>

9<smiles>C=C[C@H]1OC2(CC2)CC(=C)[C@@H]1O</smiles>

19

Scheme 3.

Synthesis of epoxy alcohol derivatives<smiles>C=C[C@@H]1OC2(CC2)C[C@@]2(CO2)[C@@H]1O</smiles> 

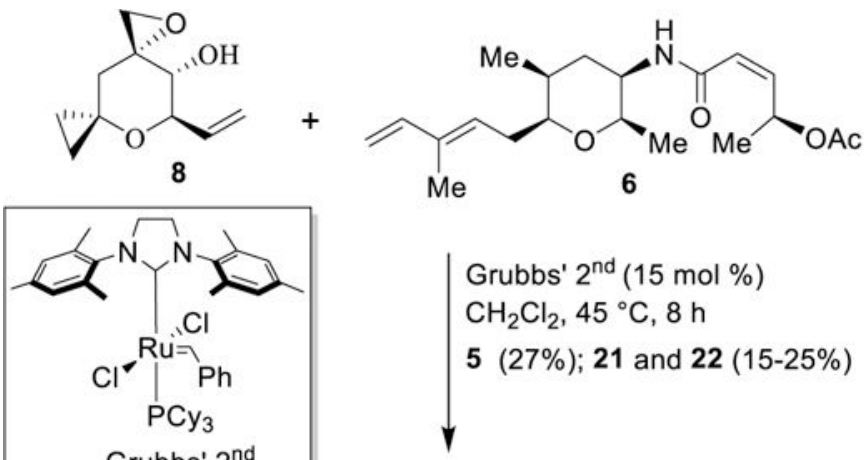

Grubbs' $2^{\text {nd }}(15 \mathrm{~mol} \%)$

$\mathrm{CH}_{2} \mathrm{Cl}_{2}, 45^{\circ} \mathrm{C}, 8 \mathrm{~h}$

5 (27\%); 21 and $22(15-25 \%)$

Grubbs' $2^{\text {nd }}$
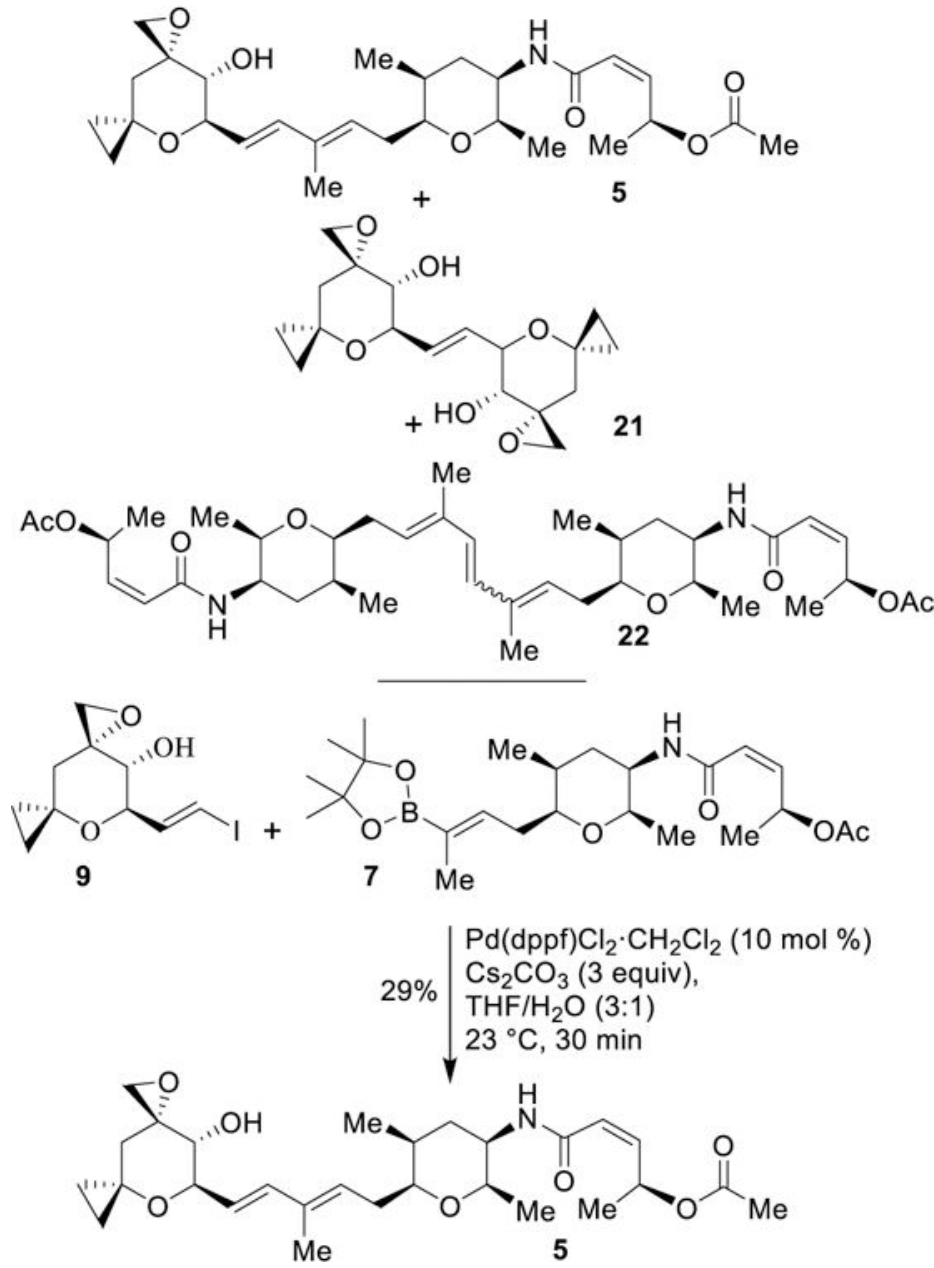

Scheme 4.

The synthesis of spliceostatin derivative $\mathbf{5}$ 